\author{
T. Mkilima \\ Pan-African University Institute for Water and Energy Sciences (including Climate Change) \\ care of Tlemcen University, Algeria, Pôle Chetouane, Tlemcen 13000 \\ e-mail: tmkilima@gmail.com
}

\title{
THE INFLUENCE OF LAND USE AND LAND COVER CHANGE ON STORMWATER RUNOFF IN A HIGHLY URBANIZING CATCHMENT (A CASE OF MSIMBAZI CATCHMENT IN DAR ES SALAAM CITY)
}

\begin{abstract}
A hydrological pattern of any catchment is highly affected or determined by how land is being used within the particular catchment. Other determining factors may include but not limited to climatic condition as well as the catchment size. This study investigated the potential effects of land use/land cover changes on stormwater runoff in a highly urbanizing catchment, for a case of Msimbazi catchment in Dar es Salaam, Tanzania. Three different years (1998, 2009 and 2018) were selected and as case studies. The extreme 100-year rainfall event of December 2011 was used to develop the meteorological model in the Hydrologic Modeling System (HEC-HMS). The ArcGIS and HEC-Geo HMS tools were used to prepare the datasets for the event-based rainfall-runoff simulation in HEC-HMS. The extent of land use/ land cover changes with time was investigated using Supervised approach in ArcGIS. The general modelling process based on the Soil Conservation Service (SCS) Curve Number (CN). From the analysis results it was observed that, the land surface cover in the catchment has been rapidly changing; for instance, developed low intensity category coverage changed from approximately $61.7 \%$ to $16.8 \%$ in 2018 . The change in terms of land surface cover translates to an increase of about $23.08 \%$ from 1998 to 2018 of the computed peak discharges. The peak inflows for all the detention basins were observed in the extreme event of 20 December 2011. The designed detention basins are capable of capturing up to $65 \%$ of runoff to make the catchment safe from the flooding incidents.
\end{abstract}

Key words: ArcGIS, detention basins, HEC-HMS, land use, rainfall-runoff simulation.

\section{Т. Мкилима}

Тлемсен университетіндегі Пан-Африка университетінің Су және энергетика ғылымдары институты (к^иматтың өзгеруін қоса), А^жир, пошта жәшігі 119 | Четуан өрісі, Тлемсен 13000

e-mail: tmkilima@gmail.com

Жерді пайдалану мен топырақ-өсімдік жамылғысының өзгеруінің жоғары урбандалған өзен алабында нөсер суларының ағуына әсері

(Аар-эс-салам қаласындағы Мсимбази өзен алабының мысалында)

Кез келген өзен алабының гилрологиялық көрінісі көбінесе белгілі бір өзен алабы шегінде жердің қалай қолданылатынына байланысты. Басқа анықтайтын факторлар климаттық жағдайларды, сондай-ақ өзен алабы ауқымын қамтуы мүмкін, бірақ олармен шектелмейді. Бұл зерттеу Танзанияда Аар-эс-салам қаласындағы Мсимбази өзен алабы мысалында жоғары урбанизацияланған өзен алабындағы жауын-шашын суларына жер пайдалану және топырақ, жамылғысындағы өзгерістердің ықтимал әсерін қарастырады. Үш түрлі жыл (1998, 2009 және 2018) нақты мысалдар ретінде таңдалды және қолданылды. Гидрологиялық модельдеу жүйесінде (HEC-HMS) метеорологиялық модельді жасау үшін 2011 жылдың желтоқсан айындағы 100 жылдық жауын-шашын оқиғасы қолданы^ды. ArcGIS және HEC-Geo HMS құра^дары HEC-HMS оқиғаларына негізделген нөсер ағынын модельдеуге мәліметтер жиынтығын дайындау үшін қолданылды. Уақыт өте келе жерді пайдалану/топырақ-өсімдік жамылғысының өзгеру дәрежесі ArcGlS-тегі бақылау әдісімен зерттелді. Жалпы модельдеу процесі Soil Conservation Service (SCS) Curve Number (CN) деректерінде негізделді. Та^дау нәтижелері бойынша өзен алабындағы топырақ-өсімдік жамылғысы тез өзгеретіні байқалды; мысалы, төмен қарқындылықтың дамыған санаты жамылғысы 2018 жылы шамамен 61,7\%-дан 16,8\%-ға Аейін өзгерді. Жер бетінің жамылғысы жоспарындағы өзгеріс 1998 жылдан бастап 2018 жылға дейін есептік ең жоғары төгінділердің шамамен 23,08\%-ға артуына алып келеді. Барлық резервуарлар үшін ең жоғары ағындар 2011 жылдың 20 желтоқсанында төтенше жағдайда байқалды. Жобаланған резервуарлар су төгетін бассейнді су тасқынынан қорғау үшін ағынның 65\%-ын кешіктіре алады.

Түйін сөздер: ArcGIS, резервуарлар, HEC-HMS, жерді пайдалану, жаңбыр ағынын модельдеу. 
Институт водных и энергетических наук Панафриканского университета (включая изменение климата) при Т^емсенском университете, А^жир, Почтовый ящик 119 | Четуанское поле, Тлемсен 13000

e-mail: tmkilima@gmail.com

Влияние изменения землепомьзования и почвенно-растительного покрова на сток Аивневых вод в высокоурбанизированном водосборном бассейне (на примере водосборного бассейна Мсимбази в городе Аар-эс-Саламе)

\begin{abstract}
Гидрологическая картина ^юбого водосбора в значительной степени зависит от того, как используется земля в пределах конкретного водосбора. Аругие определяющие факторы могут вк^ючать, помимо прочего, климатические условия, а также размер водосбора. В данном исследовании рассматривается потенциальное воздействие изменений в землепользовании/ почвенном покрове на сток мивневых вод в высокоурбанизированном водосборе на примере водосбора Мсимбази в городе Аар-эс-Саламе, Танзания. Три разных года (1998, 2009 и 2018) были выбраны и использованы в качестве конкретных примеров. Аля разработки метеорологической модели в Системе гидрологического моделирования (HЕС-HMS) использовалось экстремальное за 100 лет событие выпадения осадков в декабре 2011 года. Инструменты ArcGIS и HEC-Geо HMS были использованы Аля подготовки наборов данных Аля моделирования мивневого стока на основе событий в HEC-HMS. Степень изменения землепользования/почвенно-растительного покрова по истечению времени была исследована с помощью метода супервизии в ArcGIS. Общий процесс моделирования основывался на данных Soil Conservation Service (SCS) Curve Number $(\mathrm{CN})$. По результатам анализа было замечено, что почвенно-растительный покров на водосборе быстро изменяется; например, покрытие развитой категории низкой интенсивности изменилось приблизительно с 61,7\% до 16,8\% в 2018 году. Изменение в плане покрытия поверхности земли приводит к увеличению расчетных пиковых сбросов примерно на 23,08\% с 1998 по 2018 гоА. Пик притока во все водосборные бассейны наблюдался во время чрезвычайного события 20 декабря 2011 года. Спроектированные резервуары способны задержать до 65\% стока, чтобы обезопасить водосборный бассейн от наводнений.
\end{abstract}

Ключевые слова: ArcGIS, резервуары, HEC-HMS, землепользование, моделирование Аождевого стока.

\section{Introduction}

Efficient stormwater runoff management practices can protect one of our most important natural resources, properties and human lives. Increased impervious surfaces due to land-use changes magnify the demolishing power of floods as it increases the amount of stormwater runoff generated. However, estimation of rainfall-runoff and its relation to flood is a difficult task due to the influence of different complex factors.. The impervious surfaces may significantly affect the hydrologic patterns of catchments (McGrane 2016; Zhou et al. 2014; Shuster et al. 2005). Generally, hydrology may be defined as the movement of the earth's water in relation to land (Şen 2020), while land cover refers to anything that covers the earth's surface including forests, wetlands, impervious surfaces as well as the open water (Potapov et al. 2020). The degree to which land use/ land cover in a particular catchment is affected is highly dependent on natural and socio-economic factors (Schueler, Kuemmerle, and Schröder 2011).
In rapidly urbanizing catchments, an increase in stormwater runoff quantity may lead to numerous serious problems such as flash floods, soil erosion and alteration of an ecosystem (Chen et al. 2021). Changes in land use usually affect stormwater runoff flow characteristics as much water has to flow on the surfaces rather than infiltrating to the ground due to an increase in impervious surfaces leading to serious flooding incidents. In such cases, detention basins can be used to control or reduce the problem. Detention basins are designed to capture and slow stormwater runoff to prevent downstream flooding, reduce the extent of soil erosion, extend water flow period in the river which will also provide water for ecological conservation as well as provide water for none portable uses (Terêncio et al. 2020).

The need to promote stormwater management technologies in Tanzania is reinforced by the fact that stormwater management is inadequate leading to extreme flooding incidents in places like Dar es Salaam. The problem is exacerbated by a number of factors such as poor planning systems with residents 
living in unplanned, largely informal settlements (Seleman et al. 2020).

With the rapid urbanization in Dar es Salaam (Bhanjee and Zhang 2018), the catchments within the city are also under high pressure where the uses of the land are also rapidly changing.

In the recent past, the Msimbazi catchment has been subjected to changes in hydrologic behavior as the catchment is now more intermittent with more serious flash-flood incidents (Valimba and Mahe 2020). Unfortunately, linking between the impact of rapid urbanization and the nature of runoff in highly urbanizing catchments has been always a global challenge. The phenomenon is highly linked to the fact that little has been reported on the proper ways of investigating the trend of a catchment urbanization with time. Lack of sufficient and high-quality data as well as expertise issues are of significant challenge for execution of studies in the field.

The SCS curve number method is a simple, widely used and efficient method for determining the amount of runoff from a rainfall even in a particular area. Although the method is designed for a single storm event, it can be scaled to find average annual runoff values. The requirements for this method are very low, rainfall amount and curve number. The curve number is based on the area's hydrologic soil group, land use, treatment and hydrologic condition. The general equation for the SCS curve number method is summarized in Equation 1 (Purdue University 2021).

$$
Q=\frac{\left(P-I_{a}\right)^{2}}{\left(P-I_{a}\right)+S}
$$

Whereby, Q is computed runoff depth (in), $\mathrm{P}$ is rainfall (in), $\mathrm{S}$ is the potential maximum retention after runoff begins, and $I_{a}$ stands for initial abstractions.

In this study, the response of stormwater runoff on the land use/land cover change in a highly urbanizing catchment is investigated for a case of the Msimbazi catchment in Dar es Salaam, Tanzania. Landsat images are used to investigate the extent of land use/land cover change and then combined with soil data for Curve Number $(\mathrm{CN})$ generation. To capture one of the worst scenarios in the impact of land-use change on the stormwater runoff generated, the rainfall data for the December 2011 extreme event was applied to all the three selected study years. The detention basins were designed to capture and slow stormwater runoff to prevent downstream flooding, reduce the extent of soil erosion, extend water flow period in the river which will also provide water for ecological conservation as well as provide water for none portable uses.

\section{Materials and methods}

\section{Description of the study area}

The Msimbazi catchment is one of the biggest Catchments located in Dar es Salaam between latitudes $6^{\circ} 27^{\prime}$ and $7^{\circ} 15$ south of the Equator and between longitudes $39^{\circ}$ and $39^{\circ} 33^{\prime}$ East of Greenwich. The Msimbazi river flows across Dar es Salaam City all the way from the higher areas of Kisarawe district (Kisarawe hills) in the Coastal region and discharges into the Indian Ocean as shown in Fig. 1 below.

The rainy period of the year within the catchment and Dar es Salaam in general normally lasts for up to 9 months, starting from September to around July 4. Also, the rainfall within the catchment is characterized by a sliding 31-day rainfall of at least 0.5 inches. The month with the most rain in Dar es Salaam is April, with an average rainfall of 6.7 inches. The most dry period of the year in Dar es Salaam ranges from July to September. In Dar es Salaam, the wet season is hot and mostly cloudy while the dry season is mostly warm, characterized by windy atmosphere, and mostly clear; and it is oppressive year-round. Over the course of the year, the temperature typically varies from $68^{\circ} \mathrm{F}$ to $90^{\circ} \mathrm{F}$ and is rarely below $65^{\circ} \mathrm{F}$ or above $92^{\circ} \mathrm{F}$. In other hand, December to February is termed as a period with relatively the most thermal stressful period to human beings in Dar es Salaam.(Ndetto and Matzarakis 2013).

In general, Dar es Salaam is characterized by a relatively high population growth, with a growth rate of approximately $6 \%$, making catchment area's population currently to be approximately 1.6 million and is projected to grow to 2.5 million people in 2030 (more than double the 2011 population of 1.2 million people). During the rainy season, the basin experiences torrential rains that often cause floods. The city's most severe and destructive flooding takes place in the Msimbazi flood plain (in the Lower Msimbazi Basin), putting residents, livelihoods, properties and critical infrastructure at risk (Sauka 2019). 


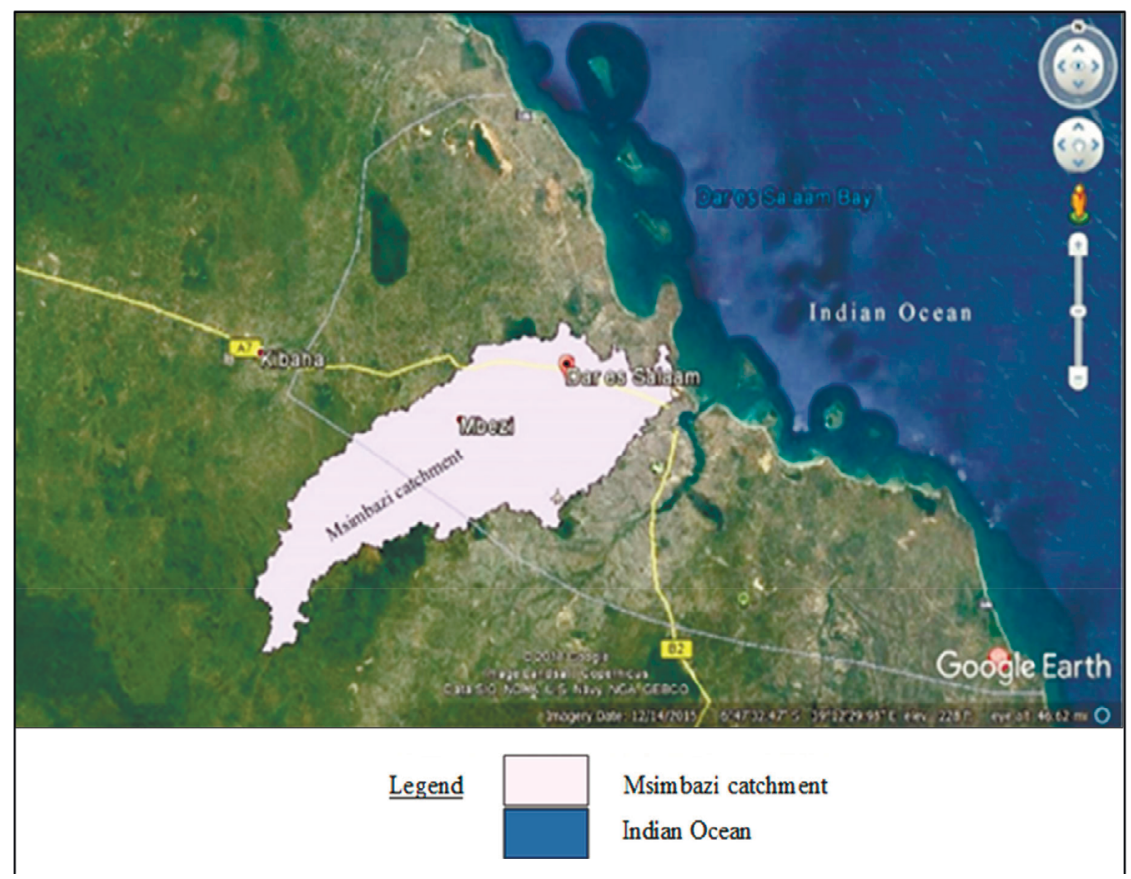

Figure 1 - Msimbazi catchment on Google Earth

Land use/land cover analysis, Digital Elevation Model processing, runoff simulation and reservoir simulation

In this study, the Digital Elevation Model was acquired from the official website of the United States Geological Survey (USGS) and then processed in ArcGIS 10.5 software packages for watershed delineation. Landsat images for the selected study years were collected from the official website of the United States Geological Survey (USGS) and then processed in ArcGIS for the Land cover/land use data. Soil datasets from Soil and Terrain Database for Southern Africa (SOTERSAF) were also processed in ArcGIS then merged with Land cover/land use data for the Curve Number generation. Rainfall datasets collected from the Tanzania Meteorological Agency were also used in the meteorological model during the hydrological model development. HEC-HMS software version 4.2.1 was used for the rainfall-runoff simulation and the design of the reservoirs. The flow chart is illustrated in Fig.2 below.

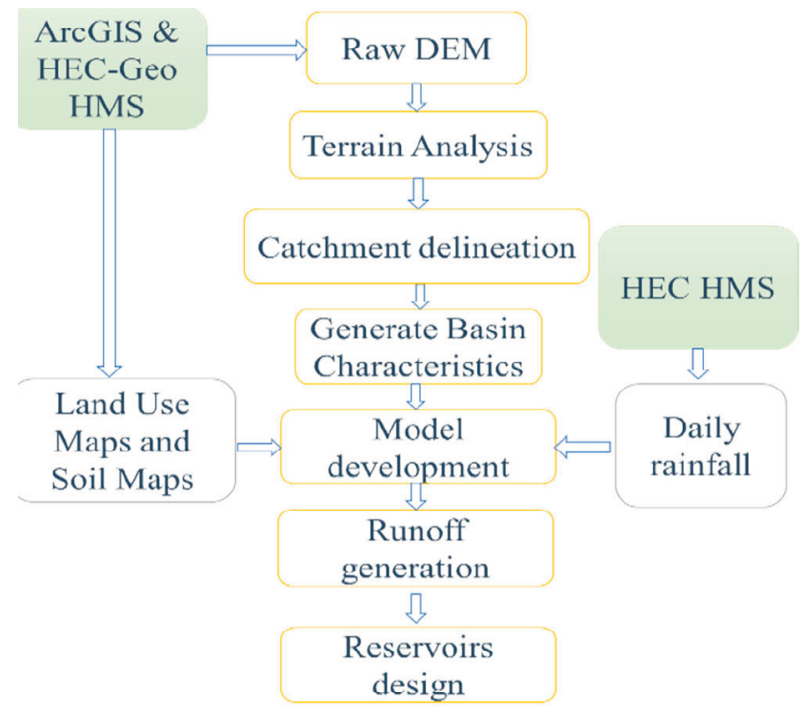

Figure 2 - Flow chart 
Land use/land cover analysis

Field investigations were done in selected parts of the catchment for the study area characterization and existing situation analysis. Satellite images for 1998, 2009 and 2018 of the catchments were selected based on the quality of data and the available resolution for the Msimbazi River watershed which is the major watershed located in Dar es Salaam and then processed in ArcGIS using the supervised method of the Image Analysis tool.
Digital Elevation Model processing for catchment delineation

Hydrological characteristics of the catchment were extracted from the Digital Elevation model using ArcGIS and GIS extension tools ranging from the DEM reconditioning in Arc Hydro tools to HMS project creation in HEC-Geo HMS tool.

All the procedures for the catchment delineation are summarized in Fig. 3.

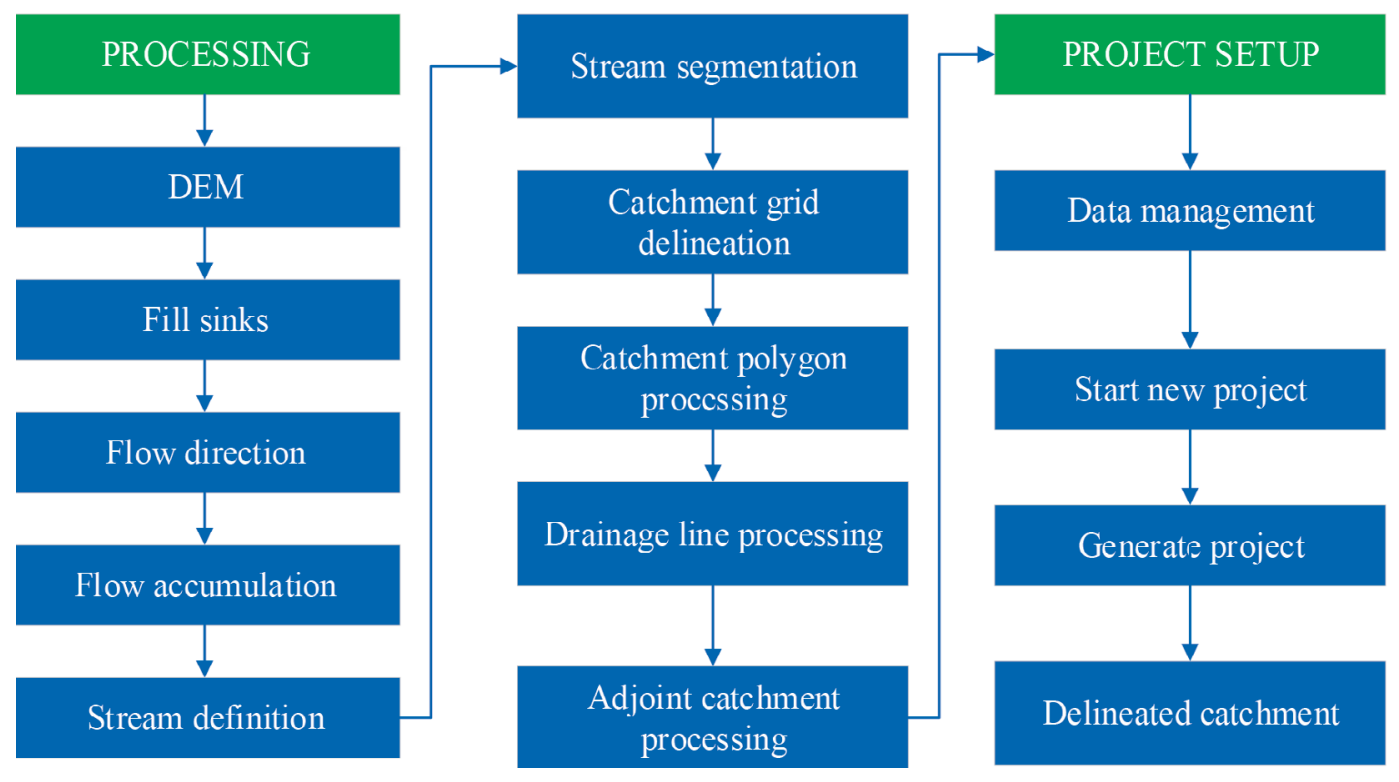

Figure 3 - Catchment delineation processes

\section{Rainfall-runoff simulation}

The hydrological modelling was accomplished by dividing the watershed into different subcatchments. To compute infiltration loss, the SCS $\mathrm{CN}$ method was used; converting excess rainfall to runoff model, the SCS unit hydrograph was used, and channel flow routing accomplished by using the simple Lag routing method of the HECHMS model. The HEC HMS model was used for rainfall-runoff simulation to quantify the amount of runoff generated with respect to the land use and precipitation data for the runoff dentation facilities design.

\section{Reservoir routing}

The reservoirs or detention ponds/basins were designed in HEC HMS; where the Paired Data Manager file was created in order to create storagedischarge curve. The Storage-Discharge method was used to define the storage method with storagedischarge curve which was created in the Paired Data Manager. The Inflow=Outflow method was used in the HEC HMS.

\section{Results and discussion}

\section{Land use/land cover analysis}

The land use/land cover analysis based on Supervised approach in ArcGIS was accomplished. From the analysis results it was observed that, the land surface cover in the catchment has been rapidly changing; for instance, developed low intensity category coverage changed from approximately $61.7 \%$ to $16.8 \%$ in 2018 . However, the shift in terms of low intensity development surface cover was observed from 1998 to 2009 whereby the coverage changed from $61.7 \%$ to $21.1 \%$. Then from 2009 to 2018 the low intensity coverage changed from $21.1 \%$ to $16.8 \%$. The phenomenon shows that, the trend of converting the undeveloped land to developed one has been decreasing with the decrease in the accessible less developed surface.

Contrary to the low intensity developed areas that have been decreasing in the catchment, the high intensity developed areas were observed to be increasing with time. However, the increasing 
pace is a bit low compared to the increasing rate of the medium intensity development. In a study conducted by Sheeraz Memon et al., for Yongin watershed in Korea (Memon et al. 2013), it was also observed that, urbanization activities have significant impact on the state of the catchment; whereby, dry field, paddy field, forest, and ground cover were changed to bare land about $61,96,13$, and $9 \%$, respectively. Moreover, in the literature, urbanization in catchments has been observed to be a difficult thing to be investigated and potentially linked to some problems, including; effects of habitat complexity on instream macroinvertebrate assemblages (White and Walsh 2020), impacts on floods, droughts and the overall river regime (Oudin et al. 2018), as well as impacts on annual runoff and actual evapotranspiration (Kalantari et al. 2017).

Table 1 - Land use coverage in percentage

\begin{tabular}{|c|c|c|c|}
\hline \multirow{2}{*}{ Type of land use } & \multicolumn{3}{|c|}{ Coverage per cent of land use (\%) } \\
\cline { 2 - 4 } & Year: 1998 & Year: 2009 & Year: 2018 \\
\hline Water bodies & 0.128609 & 0.258491 & 0.436798 \\
\hline Forest & 8.415803 & 14.69457 & 1.858241 \\
\hline Developed, high intensity & 3.823405 & 13.42444 & 6.76884 \\
\hline Developed, medium intensity & 25.96702 & 50.48973 & 16.81962 \\
\hline Developed, low intensity & 61.66516 & 21.13276 & 100 \\
\hline Total & 100 & 100 & \\
\hline
\end{tabular}

\section{Digital Elevation Model processing}

The Msimbazi catchment Digital Elevation Model processing was successfully accomplished where the boundary of the catchment and its streams, were properly computed by the ArcGIS software packages. Figure 3 below shows a well-drained catchment with up to four stream orders. In the process, the simulated fourth, third order and most of the second-order streams, matched perfectly with existing streams. Although some of the first-order streams could not be captured in the delineation process due to DEM resolution and stream threshold issues. The DEM reconditioning process did a good job in localizing streams in their right paths especially for the flat areas such as downstream of the catchment. Generally, the whole process of the GIS-based map delineation of Msimbazi catchment worked well to delineate and localize the natural runoff routes. Also, in the process, 151 sub-basins (before merged) and 83 junctions were generated (Fig. 3).

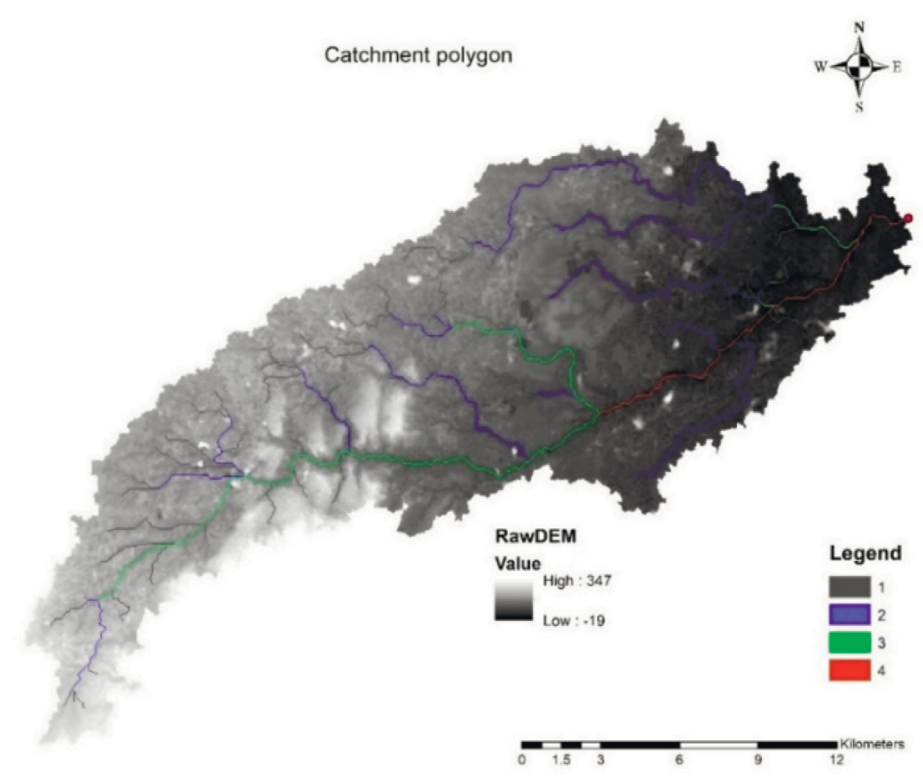

Figure 4 - Raw DEM and stream order 


\section{Rainfall-runoff simulation}

The SCS loss method relies on curve number (CN) to determine excess precipitation and losses within each sub-basin. Based on the simulated daily rainfall, peak discharge of each study year was obtained. Table 1 below shows the peak runoff discharges, which are; $355.7 \mathrm{~m}^{3}, 402.7 \mathrm{~m}^{3}$ and 437.8 $\mathrm{m}^{3}$ for the year 1998, 2009 and 2018, respectively. Translating to a peak discharge increase of about $23.08 \%$ from 1998 to 2018 .

It has to be noted that in the investigation process all other parameters were kept constant while changing land use/land cover data based on the study years. In that matter, the observed changes in terms of simulated peak discharges are solely based on the land use/land cover data. The results reveals further that there is a significant relationship between land use/land cover change and the characteristics of stormwater runoff. That is to say that, the $61.7 \%$ to $21.1 \%$ decrease in terms of low intensity development, $3.8 \%$ to $19.8 \%$ increase in terms of high intensity development and $26 \%$ to $61.1 \%$ increase in terms of medium intensity development led to $23.08 \%$ increase in stormwater peak discharge in the catchment.

When natural vegetation is replaced with an impervious surface, the natural hydrology in the particular catchment is affected, increasing stormwater runoff and reducing groundwater recharge. The result is more frequent flooding, higher flood peak flow, lower base flow in streams, and lower water table levels. The peak discharge increase phenomenon in the catchment can be highly linked to the fact that, the impervious surfaces have the tendency of reducing the lag time of the stream hydrograph resulting from lower roughness, infiltration, interception and high runoff. Apart from the general runoff peak discharge increase, the heated surface runoff from impervious surfaces can significantly change the levels of temperature in stormwater; this is due to the fact that, the impervious surfaces absorb and store heat, which is then transmitted to surface runoff during rainfall events. In the literature, some studies have shown positive correlations between impervious surface area and stream temperature (United States Environmental Protection Agency 2021). Also, in terms of quality perspectives, in built areas with extensive impervious surfaces, natural percolation of water into the earth is hindered that makes it rush across the landscape, carrying pollutants and biological contaminants into waterways, poisoning fish, wildlife, and human beings.

Also, according to the study conducted by on the application of storm water management model to predict urban headwater stream hydrological response to climate and land cover change, it was observed that the impervious surface percentage upsurge from $5 \%$ to $17 \%$, leading to significant increases of peak discharge, flashiness, and runoff at $49.5 \%, 39.3 \%$ and $73.9 \%$, respectively, for urban watersheds (Wu et al. 2013).

Table 2 - Summary of the simulated peak discharges for each study year

\begin{tabular}{|c|c|}
\hline Year & Simulated Peak Discharge $\left(\mathrm{m}^{3} / \mathrm{s}\right)$ \\
\hline 1998 & 355.7 \\
\hline 2009 & 402.7 \\
\hline 2018 & 437.8 \\
\hline
\end{tabular}

There is a noticeable change in outflows as years move-by, from the graphs in Fig. 4, it can be observed that the outflows have been increasing with years from 1998 to 2018 which can be directly linked with the impact of land-use change as the only varying parameter. The impact is more easily noticed during the low precipitation periods. The whole phenomenon reveals that the capacity of the stormwater runoff to infiltrate into the ground has been reducing as an impact of land-use change.

\section{Reservoir routing}

The coverage area for each sub-basin contributing to the designed reservoirs in $\mathrm{km}^{2}$ and percentage as well as inflows, storages and outflows of the designed reservoirs were calculated. In HEC HMS each reservoir/detention basins was connected to its corresponding sub-basin through reaches as shown in Fig. 5. A total of 5 subbasins were extracted from the study catchment and each subbasin was connected to a reservoir at the outlet. 
In a natural situation, an increase in discharge (cubic feet/second) will result in an increase in all three parameters - the river becomes wider, deeper and flows at a higher velocity. When a stream channel can no longer accommodate increased discharge, it overflows its banks and a flood occurs. The proposed basins can be used to capture runoff during high flows and release at a controlled rate to avoid flooding incidents downstream. In general, reservoir routing can be defined as a mathematical

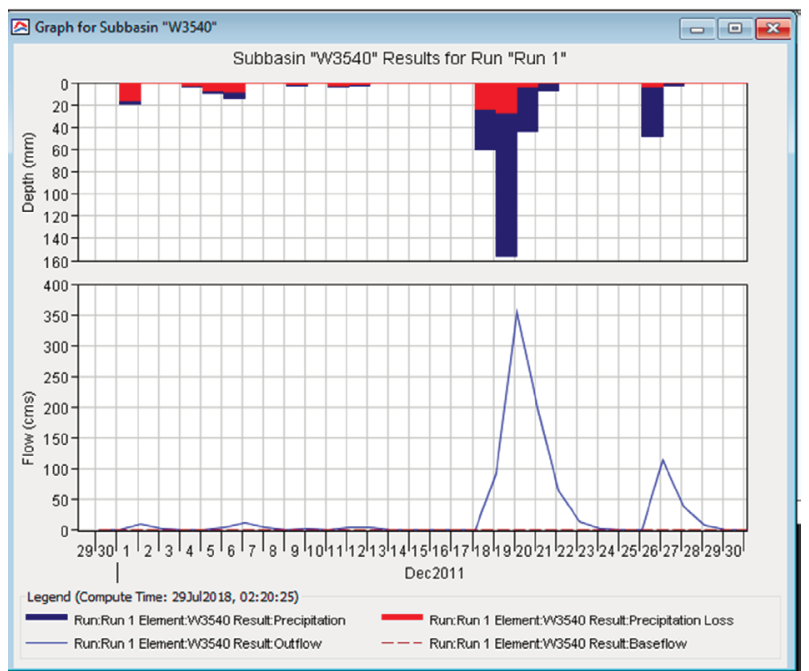

(a) procedure by which the hydrograph immediately below the reservoir is determined for the supplied inflow hydrograph(s) of the river(s) contributing to the storage of the reservoir. The routed hydrograph is characterized by the capacity to attenuate the flood peak of the inflow hydrograph. It involves the application of the continuity equation to a storage facility in which the storage volume for a particular geometry is a dependent only on the outflow (Fenton 1992).

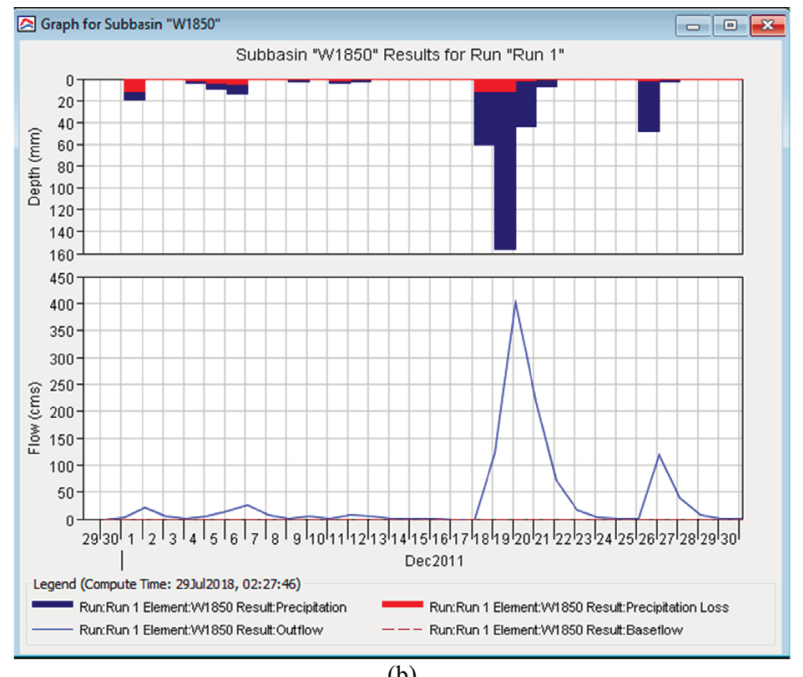

(b)

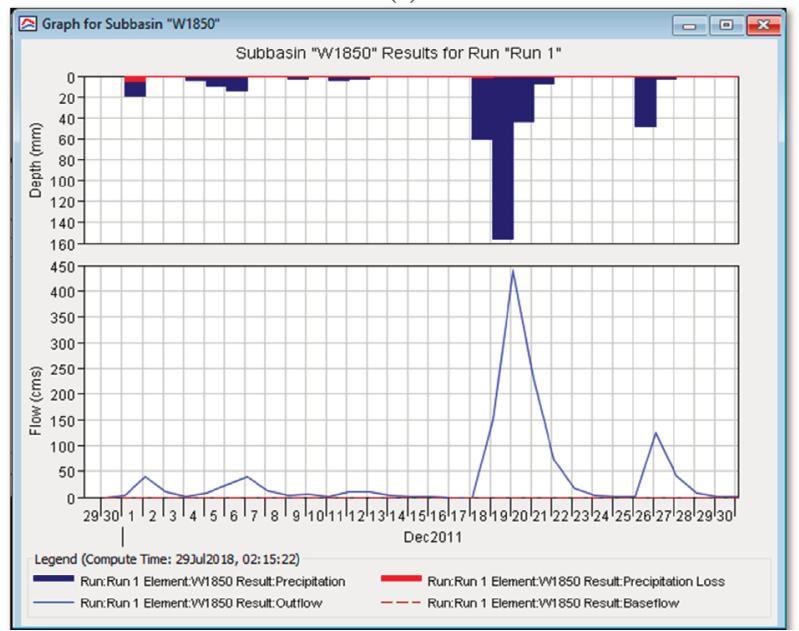

(c)

Figure 5 - Runoff modelling summary (a) 1998 (b) 2009 (c) 2018 datasets

The area of each merged sub-basin was calculated along with its percentage coverage compared to the total area of the study catchment $\left(295.9 \mathrm{~km}^{2}\right)$. The calculated area coverages for the sub-basins are summarized in Table 2 below. Each sub-basin was designed to discharge water to its corresponding reservoir. The storage capacity of each of the designed reservoirs/ detention basins also depends on the area coverage of the sub-basin discharging water to the reservoir. The peak inflows for all detention basins were observed in the extreme event of 20 December 2011, where reservoir 1 had $123.6 \mathrm{~m}^{3} / \mathrm{s}$, reservoir 2 had $43.5 \mathrm{~m}^{3} / \mathrm{s}$, reservoir 3 had $37.5 \mathrm{~m}^{3} / \mathrm{s}$, reservoir 4 had $60.5 \mathrm{~m}^{3} / \mathrm{s}$ and reservoir 5 had $19.2 \mathrm{~m}^{3} / \mathrm{s}$ as shown in Table 3 below. A total of $284.5 \mathrm{~m}^{3} / \mathrm{s}$ which is about $65 \%$ of the peak runoff discharge generated in the catchment. 


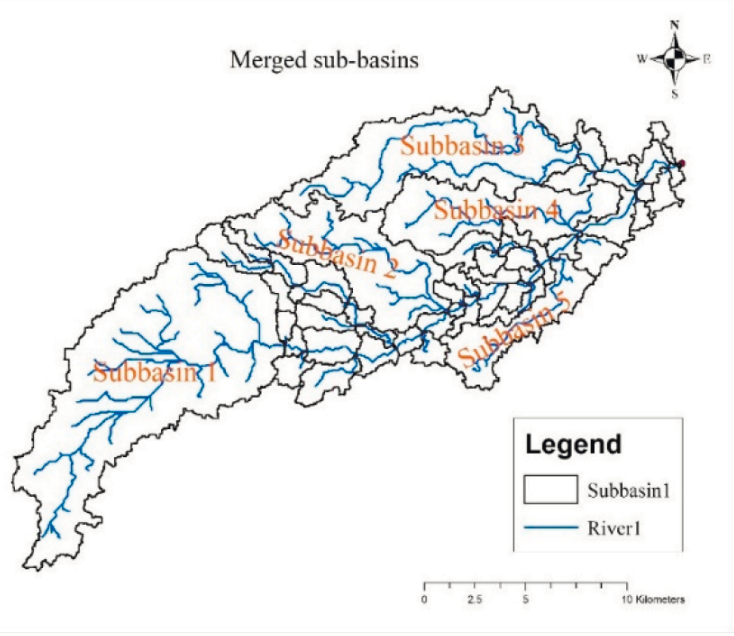

(a)

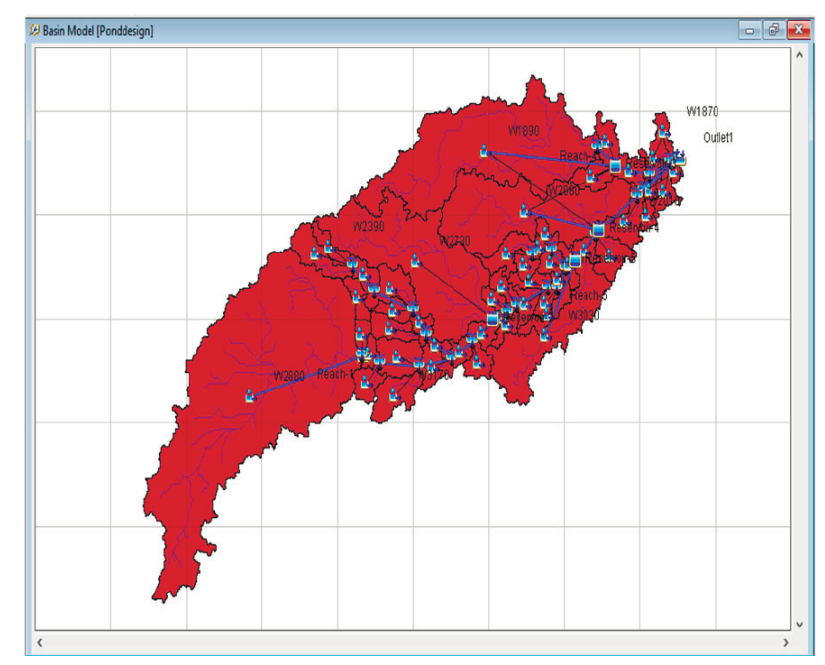

(b)

Figure 6 - Sub-basins: (a) - Merged sub-basins; (b) - Connected reaches

Table 3 - Area of each contributing sub-basin to the designed reservoirs

\begin{tabular}{|c|c|c|c|}
\hline Sub-basin & Area $\left(\mathrm{km}^{2}\right)$ & Coverage $(\%)$ & Peak discharge $\left(\mathrm{m}^{3} / \mathrm{s}\right)$ \\
\hline 1 & 92.75 & 31.34 & $123.6 \mathrm{~m}^{3} / \mathrm{s}$ \\
\hline 2 & 32.29 & 10.91 & $43.5 \mathrm{~m}^{3} / \mathrm{s}$ \\
\hline 3 & 27.68 & 9.36 & $37.5 \mathrm{~m}^{3} / \mathrm{s}$ \\
\hline 4 & 44.32 & 14.98 & $60.5 \mathrm{~m}^{3} / \mathrm{s}$ \\
\hline 5 & 14.63 & 4.94 & $19.2 \mathrm{~m}^{3} / \mathrm{s}$ \\
\hline
\end{tabular}

\section{Conclusions}

In this study, the potential effect of land use/ land cover changes on stormwater runoff in a highly urbanizing Msimbazi catchment has been investigated. The coverage area for each sub-basin contributing to the designed reservoirs in $\mathrm{km} 2$ and percentage as well as inflows, storages and outflows of the designed reservoirs were calculated. From the analysis results it was observed that, the land surface cover in the catchment has been rapidly changing; for instance, developed low intensity category coverage changed from approximately $61.7 \%$ to $16.8 \%$ in 2018 . However, the shift in terms of low intensity development surface cover was observed from 1998 to 2009 whereby the coverage changed from $61.7 \%$ to $21.1 \%$. Then from 2009 to 2018 the low intensity coverage changed from $21.1 \%$ to $16.8 \%$. The phenomenon shows that, the trend of converting the undeveloped land to developed one has been decreasing with the decrease in the accessible less developed surface. That is to say that, the $61.7 \%$ to $21.1 \%$ decrease in terms of low intensity development, $3.8 \%$ to $19.8 \%$ increase in terms of high intensity development and $26 \%$ to $61.1 \%$ increase in terms of medium intensity development led to $23.08 \%$ increase in stormwater peak discharge in the catchment. The peak inflows to all the detention basins were observed on the most extreme day of 20 December 2011. The designed reservoirs could capture a total of $284.5 \mathrm{~m}^{3} / \mathrm{s}$ which is about $65 \%$ of the peak runoff discharge generated in the catchment. As shown from this study, detention basins should be promoted as a technology for stormwater runoff management in flood-threatened areas because they can serve multiple purposes including floods control, ecological conservation, recreational purposes, soil conservation as well as providing water for supply.

\section{Acknowledgement}

This research was funded by the Science Committee of the Ministry of Education and Science of the Republic of Kazakhstan (Grant No. AP09258790). 


\section{References}

Bhanjee, Sheliza, and Charlie H. Zhang. 2018. "Mapping Latest Patterns of Urban Sprawl in Dar Es Salaam, Tanzania." Papers in Applied Geography 4 (3): 292-304. https://doi.org/10.1080/23754931.2018.1471413.

Chen, Xiaoli, Han Zhang, Wenjie Chen, and Guoru Huang. 2021. "Urbanization and Climate Change Impacts on Future Flood Risk in the Pearl River Delta under Shared Socioeconomic Pathways." Science of The Total Environment 762 (March): 143144. https://doi.org/10.1016/j.scitotenv.2020.143144.

Fenton, John D. 1992. "Reservoir Routing.” Hydrological Sciences Journal 37 (3): 233-46. https://doi.org/10/dbm77t.

Kalantari, Zahra, Carla Sofia Santos Ferreira, Rory Peter Dominic Walsh, António José Dinis Ferreira, and Georgia Destouni. 2017. "Urbanization Development under Climate Change: Hydrological Responses in a Peri-Urban Mediterranean Catchment." Land Degradation \& Development 28 (7): 2207-21. https://doi.org/10/gb4nwt.

McGrane, Scott J. 2016. "Impacts of Urbanisation on Hydrological and Water Quality Dynamics, and Urban Water Management: A Review." Hydrological Sciences Journal 61 (13): 2295-2311. https://doi.org/10.1080/02626667.2015.1128084.

Memon, Sheeraz, Ma. Cristina Paule, Shin-Jeong Park, Bum-Yeon Lee, Sunhae Kang, Raja Umer, and Chang-Hee Lee. 2013. "Monitoring of Land Use Change Impact on Stormwater Runoff and Pollutant Loading Estimation in Yongin Watershed Korea." Desalination and Water Treatment 51 (19-21): 4088-96. https://doi.org/10/gnq3vh.

Ndetto, Emmanuel L., and Andreas Matzarakis. 2013. "Basic Analysis of Climate and Urban Bioclimate of Dar Es Salaam, Tanzania." Theoretical and Applied Climatology 114 (1-2): 213-26. https://doi.org/10/f494wq.

Oudin, Ludovic, Bahar Salavati, Carina Furusho-Percot, Pierre Ribstein, and Mohamed Saadi. 2018. "Hydrological Impacts of Urbanization at the Catchment Scale." Journal of Hydrology 559 (April): 774-86. https://doi.org/10/gdjttg.

Potapov, Peter, Matthew C. Hansen, Indrani Kommareddy, Anil Kommareddy, Svetlana Turubanova, Amy Pickens, Bernard Adusei, Alexandra Tyukavina, and Qing Ying. 2020. "Landsat Analysis Ready Data for Global Land Cover and Land Cover Change Mapping." Remote Sensing 12 (3): 426. https://doi.org/10.3390/rs12030426.

Purdue University. 2021. "SCS Curve Number Method.” 2021. https://engineering.purdue.edu/mapserve/LTHIA7/documentation/scs.htm.

Sauka, Siyasanga. 2019. "Climate Resilience in Developing Cities: Msimbazi Basin, Dar Es Salaam,” July, 14.

Schueler, Vivian, Tobias Kuemmerle, and Hilmar Schröder. 2011. "Impacts of Surface Gold Mining on Land Use Systems in Western Ghana." AMBIO 40 (5): 528-39. https://doi.org/10.1007/s13280-011-0141-9.

Seleman, Amour, Sara Gabrielsson, Tolly S. A. Mbwette, and Richard Kimwaga. 2020. "Drivers of Unhygienic Desludging Practices in Unplanned Settlements of Dar Es Salaam, Tanzania." Journal of Water, Sanitation and Hygiene for Development 10 (3): 512-26. https://doi.org/10.2166/washdev.2020.179.

Şen, Zekâi. 2020. "Hydrology.” In Advances in Science, Technology and Innovation, 53-87. https://doi.org/10.1007/978-3-03001542-8_3.

Shuster, W. D., J. Bonta, H. Thurston, E. Warnemuende, and D. R. Smith. 2005. "Impacts of Impervious Surface on Watershed Hydrology: A Review." Urban Water Journal 2 (4): 263-75. https://doi.org/10.1080/15730620500386529.

Terêncio, D.P.S., L.F. Sanches Fernandes, R.M.V. Cortes, J.P. Moura, and F.A.L. Pacheco. 2020. "Flood Risk Attenuation in Critical Zones of Continental Portugal Using Sustainable Detention Basins.” Science of The Total Environment 721 (June): 137727. https://doi.org/10.1016/j.scitotenv.2020.137727.

United States Environmental Protection Agency. 2021. "Urbanization - Temperature.” 2021. https://www.epa.gov/caddis-vol2/ caddis-volume-2-sources-stressors-responses-urbanization-temperature.

Valimba, Patrick, and Gil Mahe. 2020. "Estimating Flood Magnitudes of Ungauged Urban Msimbazi River Catchment in Dar Es Salaam, Tanzania." Tanzania Journal of Engineering and Technology 39 (1): 59-71. https://doi.org/10.52339/tjet.v39i1.519.

White, Julia Y., and Christopher J. Walsh. 2020. "Catchment-scale Urbanization Diminishes Effects of Habitat Complexity on Instream Macroinvertebrate Assemblages.” Ecological Applications 30 (8). https://doi.org/10/gnq568.

Wu, J. Y., J. R. Thompson, R. K. Kolka, K. J. Franz, and T. W. Stewart. 2013. "Using the Storm Water Management Model to Predict Urban Headwater Stream Hydrological Response to Climate and Land Cover Change." Hydrology and Earth System Sciences 17 (12): 4743-58. https://doi.org/10/f5mg7m.

Zhou, Yuyu, Yeqiao Wang, Arthur J. Gold, Peter V. August, and Thomas B. Boving. 2014. "Assessing Impact of Urban Impervious Surface on Watershed Hydrology Using Distributed Object-Oriented Simulation and Spatial Regression." GeoJournal 79 (2): 155-66. https://doi.org/10.1007/s10708-013-9506-x. 